Original Article

\title{
Molecular classification and comparative phylogeographic study of insectivorous bat species (Pipisitrellus coromandra) from Punjab, Pakistan
}

\author{
Classificação molecular e estudo filogeográfico comparativo de espécies de morcegos \\ insetívoros (Pipistrellus coromandra) de Punjab, Paquistão
}

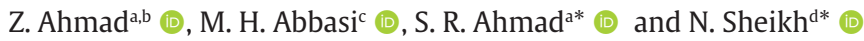 \\ ${ }^{a}$ College of Earth and Environmental Sciences, University of the Punjab, Lahore, Pakistan \\ ${ }^{b}$ Department of Environmental Sciences, Lahore College for Women University, Lahore, Pakistan \\ ' Department of Zoology, University of Okara, Okara, Punjab, Pakistan \\ ${ }^{\mathrm{d}}$ Department of Zoology, University of the Punjab, Lahore, Pakistan
}

\begin{abstract}
Molecular based identification of bat fauna in Pakistan has been relatively less explored. The current study was therefore planned to report for the first time the molecular classification of insectivorous bats (Pipistrellus coromandra) based on mitochondrion gene (COI) from Punjab, Pakistan. Specimens were collected from five different locations followed by DNA extraction with subsequent gene amplification and sequencing. All samples in the study had shown close identity matches with species (Pipistrellus coromandra) from India and (Pipistrellus tenuis) from Vietnam with percentage identity score of 96.11 and 95.58 respectively except one sequence which only revealed $86.78 \%$ identity match on Basic Local Alignment Search Tool (BLAST) and could only be assigned to genus level Pipistrellus sp. The results indicated negligible intra-population genetic distance among collected samples whereas the comparison with species from other countries had shown high intraspecific ( $P$. coromandra) and interspecific ( $P$. tenuis) mean genetic distances. The current study hence successfully proved the efficiency of COI gene as a molecular marker for species identification and in analyzing the patterns of genetic variation with species from other countries.
\end{abstract}

Keywords: Bats, COI gene, Pakistan, phylogeny, taxonomy.

\begin{abstract}
Resumo
A identificação com base molecular da fauna de morcegos no Paquistão tem sido relativamente menos explorada. Portanto, o estudo atual foi planejado para relatar pela primeira vez a classificação molecular de morcegos insetívoros (Pipistrellus coromandra) com base no gene da mitocôndria (COI) de Punjab, Paquistão. As amostras foram coletadas em cinco locais diferentes, seguidas pela extração de DNA com subsequente amplificação e sequenciamento do gene. Todas as amostras no estudo mostraram coincidências de identidade próximas com espécies (Pipistrellus coromandra) da Índia e (Pipistrellus tenuis) do Vietnã, com pontuação de identidade percentual de 96,11 e 95,58, respectivamente, exceto uma sequência que revelou apenas $86,78 \%$ de correspondência de identidade na Ferramenta de Pesquisa de Alinhamento Local Básico (BLAST), a qual só poderia ser atribuída ao nível de gênero Pipistrellus sp. Os resultados indicaram distância genética intrapopulacional desprezível entre as amostras coletadas, enquanto a comparação com espécies de outros países mostrou altas distâncias genéticas intraespecíficas ( $P$. coromandra) e interespecíficas (P. tenuis) médias. O presente estudo, portanto, comprovou com sucesso a eficiência do gene COI como marcador molecular para identificação de espécies e análise dos padrões de variação genética com espécies de outros países.
\end{abstract}

Palavras-chave: Morcegos, gene COI, Paquistão, filogenia, taxonomia.

\section{Introduction}

The efficacy of mitochondrial gene cytochrome $c$ oxidase subunit I (COI) for species identification has been validated across many taxa with its successful implication in estimating the species richness and establishing the cryptic diversity ranging from fish to mammalian species. The short-standardized sequence of barcode gene distinguishes specimens based on interspecific genetic variations among species which is far greater than intraspecific or within speices variation (Herbert et al., 2003). 
According to inferences from DNA barcode data about $95 \%$ of animal species possess distinct barcode sequences. Kerr et al. (2007) and Kerr et al. (2009) recognized unique barcodes of birds from North America and Argentina, respectively. Similar diagnostic barcode sequences had been found for 207 Australian fish species (Ward et al., 2005) while Hajibabaei et al. (2006) had identified 98\% of Costa Rican lepidopterans. Among mammalian fauna barcode data of Neotropical bats and small mammals had successfully been used in species discrimination (Clare et al., 2007; Borisenko et al., 2008).

Bats being the second largest order (Chiroptera) constitutes highly diversified group representing about $20 \%$ of all the mammals with above 1100 described species (Reeder et al., 2007) but likelihood of overlooked taxa is exceptionally high because of their nocturnal and volant behaviour. Many cases of cryptic species have been reported in Genus Myotis and Plecotus (Mayer and Helversen, 2001) and among species studied in Neotropics (Baker and Bradley, 2006; Clare et al., 2007; Borisenko et al., 2008; Clare, 2011; Clare et al., 2011) and Southeast Asia (Francis et al., 2010).

The geographical location of Pakistan uniquely places it between two of the world's major zoogeographic regions; the Indomalayan or Oriental and the Palaearctic region which offers unique blending leading the country to have diversified forms of fauna and flora (Mahmood-ulHassan et al., 2009). It has been estimated that diversity of bats species in Pakistan constitutes about $28 \%$ of mammalian species comprising 8 families, 23 genera and 50 species. Diversity associated with bat fauna could be very high in the country owing to the lack of application of molecular techniques for species identification of this group.

Bats belonging to genus Pipistrellus have widespread distribution across the world and is represented by 51 species globally with 12 species recorded from Indian subcontinent (Koopman, 1993) whereas 8 species have so far been reported from Pakistan (Roberts, 1997). Previously the species has been identified from the country based on morphological data from Dir, Yakh Tangai in KPK, Chakri in Punjab (Bates and Harrison, 1997) and from Bajaur Agency, Pakistan (Javid et al., 2019).

The current research work has therefore been conducted to establish the barcode data for insectivorous bats belonging to genus Pipistrellus captured from different locations from Punjab, Pakistan. The study is also based on the hypothesis that there will be a definite genetic structuring in the species from the study area with geographically distant species.

\section{Materials and Methods}

\subsection{Sample collection}

Insectivorous bats ( $n=23$ ) were collected from different locations and habitats including urban, semi-urban and rural areas of Punjab, Pakistan and were assigned with specific codes (as shown in Table 1). Collections were made to target the bats belonging to genus Pipistrellus as identified from taxonomic expert (Dr. Arshad Javid, Associate Professor, Department of Wildlife and Ecology, University of Veterinary and Animal Sciences (UVAS) Ravi Campus Pattoki, Punjab, Pakistan).

\subsection{Ethics statement}

Appropriate permission was taken from institutional Bioethics Committee of the University of Punjab (D/503/ UZ) and Wildlife and Parks Department, Punjab, Pakistan (No.2839/DG).

\subsection{Processing of bats samples for DNA extraction and amplification}

Patagium \& hind legs tissue samples of bat specimens were processed for DNA extraction following the guidelines provided by (Fan and Gulley, 2001). COI gene was amplified using the primer pair PBCOIdF and PBCOIdR1 reported by (Ahmad et al., 2019). Briefly a total volume of $25 \mu \mathrm{l}$ Polymerase chain reaction (PCR) mixture was set up consisting of $8.5 \mu \mathrm{l}$ ultra-pure water, $12.5 \mu \mathrm{l}$ PCR master mix (2x); $3 \mu \mathrm{l}$ of template DNA (15ng/ $\mu \mathrm{l})$ and $0.5 \mu \mathrm{l}$ of each primer $(10 \mu \mathrm{M})$. The PCR cocktails were subjected to touch down thermal cycling programme with following conditions: $95^{\circ} \mathrm{C}$ for $10 \mathrm{~min}, 10$ cycles of $94^{\circ} \mathrm{C}$ for $30 \mathrm{sec}$, $60-50{ }^{\circ} \mathrm{C}$ for $30 \mathrm{sec}$ (touchdown step with $1{ }^{\circ} \mathrm{C}$ decrease per cycle), $72{ }^{\circ} \mathrm{C}$ for $45 \mathrm{sec}$; then 25 cycles of $94{ }^{\circ} \mathrm{C}$ for $30 \mathrm{sec} ; 50{ }^{\circ} \mathrm{C}$ for $30 \mathrm{sec}, 72{ }^{\circ} \mathrm{C}$ for $45 \mathrm{sec}$. The amplified

Table 1. Sampling locations with their codes, geographic coordinates and number of specimens (n) analyzed from each location and GenBank accession numbers for COI gene.

\begin{tabular}{|c|c|c|c|c|c|}
\hline \multirow{2}{*}{ Sr. No. } & \multirow{2}{*}{ Location/District \& codes } & \multicolumn{2}{|c|}{ Geographic coordinates } & \multirow{2}{*}{$\begin{array}{l}\text { Sampling codes } \\
\text { with No. of } \\
\text { Individuals ( } n \text { ) }\end{array}$} & \multirow{2}{*}{$\begin{array}{c}\text { COI GenBank } \\
\text { accession \# }\end{array}$} \\
\hline & & Latitude (N) & Longitude (E) & & \\
\hline 1. & Kahna/District Lahore (KA) & $31.3739^{\circ} \mathrm{N}$ & $74.3675^{\circ} \mathrm{E}$ & KA-I to KA-VII (7) & $\begin{array}{c}\text { MK876220; } \\
\text { MK961304-MK961309 }\end{array}$ \\
\hline 2. & Head Baloki/District Kasur (HB) & $31.2222^{\circ} \mathrm{N}$ & $73.8589^{\circ} \mathrm{E}$ & HB-I to HB-IV (4) & МK961291-МK961294 \\
\hline 3. & Chak 107 NB/District Sargodha (SA) & $31.9669^{\circ} \mathrm{N}$ & $72.5724^{\circ} \mathrm{E}$ & SA-I to SA-II (2) & МK961289-МK961290 \\
\hline 4. & Chak Piru/District Gujranwala (GJ) & $32.1821^{\circ} \mathrm{N}$ & $74.2692^{\circ} \mathrm{E}$ & GJ-I to GJ-V (5) & МК961295-МК961299 \\
\hline 5. & Chak No. 23/2L/District Okara (OR) & $30.8443^{\circ} \mathrm{N}$ & $73.5521^{\circ} \mathrm{E}$ & OR-I to OR-V (5) & $\begin{array}{c}\text { MK961300- } \\
\text { MK961303; MN180079 }\end{array}$ \\
\hline
\end{tabular}


products were successfully electrophoresed with $1 \%$ agarose gel, verified for their correct size followed by PCR products purification and sequencing outsourced from DNA sequencing facility in Malaysia.

\subsection{Data analysis}

The consensus sequences were generated after trimming the low-quality tails at the beginning \& end of each sequence chromatogram and followed by Basic Local Alignment Search Tool (BLAST) (http://www.ncbi. nlm. nih.gov/BLAST/). Sequences were assessed for their identity from the GenBank Database while sequences generating $>90 \%$ identity were used as reference sequences for mutation analysis.

In total all available data ( 59 sequences) were retrieved from BOLD (www.barcodinglife.org) for similar species (Pipistrellus coromandra) and Pipistrellus tenuis because of close similarity matches with species under study. Sequences were then aligned by CLUSTALW using MGEGA7 software and length of all sequences was adjusted into equal fragments ( $550 \mathrm{bp}$ ) while sequences below this length were not included in the final analysis. Kimura 2-parameter (K2P) distance model (Kimura, 1980) in MEGA7 was used for sequence divergence. All positions containing gaps and missing data were eliminated using the complete delete option and vertebrate mitochondrial code was applied in the analysis.

A comparative phylogeographic analysis through Neighbour-Joining (NJ) tree (Saitou and Nei, 1987) with branch support assessed by bootstrapping with 1000 replicates in the computer program MEGA7 (Kumar et al., 2016) was performed to provide a graphic representation of the divergence patterns of identified specimens in the study with conspecifics populations and congeneric species from other geographic regions.

For each group diversity indexes such as (haplotype diversity (Hd), total number of haplotypes (Ht) and nucleotide diversity $(\pi)$ were calculated using DnaSP 5.0 (Librado and Rozas, 2009).

\section{Results}

The target fragment of mitochondrial DNA (mtDNA) COI gene was successfully amplified for insectivorous bat species collected from different locations of Punjab, Pakistan. All the sequences generated in the study were submitted to NCBI GenBank with accession numbers given in (see Table 1).

\subsection{Molecular Taxonomic Identification}

Consequences sequences from all specimens revealed their identity to species Pipistrellus coromandra (Accession No: MG821188) from India with \% identity score of 96.11 showing 21 single nucleotide polymorphisms (SNPs) and Pipistrellus tenuis (Accession No: HM541298) from Vietnam with \% identity score of 95.58 depicting point mutations of 24 (see Figures 1-2). The sequence of one specimen (OR-V) from population Chak No. 23/2L/District Okara (OR) had shown different results with the closest $86.78 \%$ identity match with species Pipistrellus pipistrellus (Accession No: JF443081) from Russia therefore could only be identified upto genus level Pipistrellus sp.

\subsection{Estimation of intraspecies and interspecies K2P distances}

The specimens of $P$. coromandra collected from different locations in the current study had shown mean intraspecific genetic distance of $(0.073 \pm 0.07)$. Whereas for the data collected from BOLD the amount of genetic differentiation within each population (intraspecific genetic distances) was not greater than $1 \%$ for most of the groups analyzed. But for species identified as $P$. coromandra $(n=2)$ from India had shown very high intraspecific genetic divergence $(15.65 \pm 2.33)$ which could be related to either misidentification indicating that two specimens might be congeneric species (see Table 2 ). The analysis of genetic distances between $P$. coromandra species $(\mathrm{n}=19)$ identified in the current study with similar and closely related species from other geographical locations had shown high intraspecies genetic distances ranging from $(10.06 \pm 1.39)$ to $(20.95 \pm 2.92)$ with $P$. coromandra from India and sequences from an unknown source respectively whereas interspecies genetic distances with species $P$. tenuis were not greater than $5 \%$ (see Table 2 ). The only sequence identified as Pipistrellus sp. had shown the high genetic distance of $(24.96 \pm 3.40)$ with $P$. coromandra species $(n=19)$ from the current study (Table 2).

\subsection{Phylogeographic Analysis}

In total $(n=20)$ sequences were further analyzed in the study out of total $(n=23)$ sequences generated along with sequences obtained from BOLD $(n=59)$ which were aligned in order to determine the population genetic structure over the wide geographical extent. An NJ tree was constructed including the complete data. The topology of the phylogenetic tree had shown the existence of two genetic clusters (A \& B). The cluster A had $P$. coromandra species from current study and one specimen from neighbouring country India along with closely related species $P$. tenuis from Laos and Vietnam whereas the group B had $P$. coromandra species from India, China, Laos, Vietnam and Pakistan, tribal areas (as shown in Figure 3).

\subsection{Diversity indices}

Based on 550 bp mtDNA sequences of 79 bats specimens in total 27 haplotypes were identified with haplotype diversity of $(0.913 \pm 0.018)$ and nucleotide diversity of $(0.08165 \pm 0.00497)$. For $P$. coromandra population from the current study minimum haplotype diversity $(0.351 \pm 0.111)$ and nucleotide diversity $(0.00072 \pm 0.00023)$ was found (see Table 3).

For other populations both haplotype diversity (Hd) and nucleotide diversity $(\pi)$ were heterogeneous with maximum Hd of (1.00 \pm 0.272$)$; for populations of $P$. cf. coromandra (Laos); P. cf. coromandra (China) and ( $1.00 \pm 0.500)$ for P. $c f$. tenuis (Vietnam) and P. coromandra (India) and minimum Hd of $(0.386 \pm 0.128)$ from $P$. tenuis population from Vietnam was noted. High $\pi(0.11905 \pm 0.05952)$ was observed for 


\begin{tabular}{|c|c|c|c|c|c|}
\hline $\begin{array}{l}\text { Score } \\
881 \mathrm{bi}\end{array}$ & $(477)$ & $\begin{array}{l}\text { Expect } \\
0.0\end{array}$ & $\begin{array}{l}\text { Identities } \\
519 / 540(96 \%)\end{array}$ & $\begin{array}{l}\text { Gaps } \\
0 / 540(0 \%)\end{array}$ & \\
\hline $\begin{array}{ll}\text { uery } \\
\text { pjct }\end{array}$ & $\begin{array}{l}1 \\
117\end{array}$ & $\begin{array}{l}\text { TAATGTGATCGTA } \\
\ldots \ldots \ldots \text {. } \ldots\end{array}$ & $\begin{array}{l}\text { ICCCATGCTTTTGT, } \\
\ldots \ldots \ldots \ldots . . .\end{array}$ & $\begin{array}{l}\text { TCTTTATAGTGATACCCATTAT } \\
\ldots \ldots \ldots \ldots \text {. } \ldots \ldots \ldots \ldots \ldots\end{array}$ & $\begin{array}{l}60 \\
17\end{array}$ \\
\hline $\begin{array}{l}\text { uery } \\
\text { bjct }\end{array}$ & $\begin{array}{l}61 \\
177\end{array}$ & $\begin{array}{l}\text { GATCGGAGGATTT } \\
\ldots \ldots \text {......... }\end{array}$ & $\begin{array}{l}\text { AACTGACTTGTTCC } \\
\ldots \ldots \ldots \ldots \text {. } \ldots\end{array}$ & $\begin{array}{l}\text { TCGGAGCCCCTGACATAGCATT } \\
\ldots \ldots \ldots \ldots \ldots \ldots \ldots \ldots\end{array}$ & 12 \\
\hline $\begin{array}{l}\text { uery } \\
\text { bjct }\end{array}$ & $\begin{array}{l}121 \\
237\end{array}$ & $\begin{array}{l}\text { TCCTCGCATGAAT } \\
\ldots \ldots \ldots \ldots \ldots \ldots\end{array}$ & ............. & 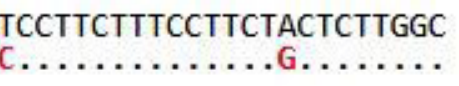 & 18 \\
\hline uery & $\begin{array}{l}181 \\
297\end{array}$ & $\begin{array}{l}\text { ATCATCCATAGTA } \\
\ldots \ldots \ldots \ldots \text { G. }\end{array}$ & $\ldots \ldots \ldots \ldots$ & $\begin{array}{l}\text { CGGTTTATCCACCTCTGGCAGG } \\
\ldots \ldots \text { C.C........... }\end{array}$ & \\
\hline $\begin{array}{l}\text { uery } \\
\text { ubjct }\end{array}$ & $\begin{array}{l}241 \\
357\end{array}$ & $\begin{array}{l}\text { АAACCTCGCTCA } \\
\cdots \cdots \cdots \cdots \cdots\end{array}$ & $\begin{array}{l}\text { GGGCCTCCGTGG } \\
\cdots \cdots \cdots \cdots \cdots\end{array}$ & $\begin{array}{l}\text { ITTTTTCCCTACACCTAGCAGG } \\
\cdots \cdots \cdots \cdots \cdots \cdots \cdots \cdots\end{array}$ & 36 \\
\hline $\begin{array}{l}\text { uery } \\
\text { bjct }\end{array}$ & $\begin{array}{l}301 \\
417\end{array}$ & $\begin{array}{l}\text { GGTATCATCAATC } \\
\ldots . \text { G. } \ldots \ldots \ldots .\end{array}$ & $\begin{array}{l}\text { GGGGCAATTAATTT } \\
\ldots \ldots \ldots \ldots \ldots\end{array}$ & $\begin{array}{l}\text { CTATTATTAATATAAAACCCCC } \\
\cdots \ldots \ldots \ldots \ldots \ldots \ldots\end{array}$ & 46 \\
\hline $\begin{array}{l}\text { uery } \\
\text { bjct }\end{array}$ & $\begin{array}{l}361 \\
477\end{array}$ & $\begin{array}{l}\text { TGCTCTTTCTCAA } \\
\text { C........... }\end{array}$ & $\begin{array}{l}\text { AAACACCATTATT } \\
\ldots \ldots \ldots \ldots \ldots\end{array}$ & $\begin{array}{l}\text { CCGGTATTAATTACAGCGGTTCT } \\
\ldots \ldots \ldots \ldots \ldots \ldots \ldots \ldots\end{array}$ & $\begin{array}{l}42 \\
5\end{array}$ \\
\hline $\begin{array}{l}\text { uery } \\
\text { bjct }\end{array}$ & $\begin{array}{l}421 \\
537\end{array}$ & $\begin{array}{l}\text { TCTTTTACTATCA } \\
\ldots \ldots \ldots \ldots \ldots \ldots\end{array}$ & $\begin{array}{l}\text { CCTGTGCTAGCCGC } \\
\ldots \ldots \ldots \ldots \ldots\end{array}$ & $\begin{array}{l}\text { CAATACTATTAACAGATCGAAA } \\
\ldots \ldots \text { T } \ldots \ldots \ldots \text { C. } \ldots\end{array}$ & 48 \\
\hline $\begin{array}{l}\text { uery } \\
\text { bjct }\end{array}$ & $\begin{array}{l}481 \\
597\end{array}$ & $\begin{array}{l}\text { TTTAAACACAACC } \\
\ldots \ldots \ldots \ldots \ldots\end{array}$ & $\begin{array}{l}\text { TCGACCCTGCCGG } \\
\ldots \ldots \text { T. } \ldots \ldots \ldots\end{array}$ & 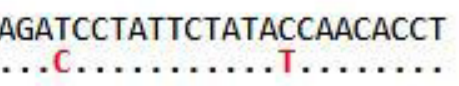 & $\begin{array}{l}5 \\
65\end{array}$ \\
\hline
\end{tabular}

Figure 1. Mutation analysis of representative sequence of specimen collected from (Kahna/District Lahore KA-III) with first top BLAST search result of species Pipistrellus coromandra from India (Accession No: MG821188).

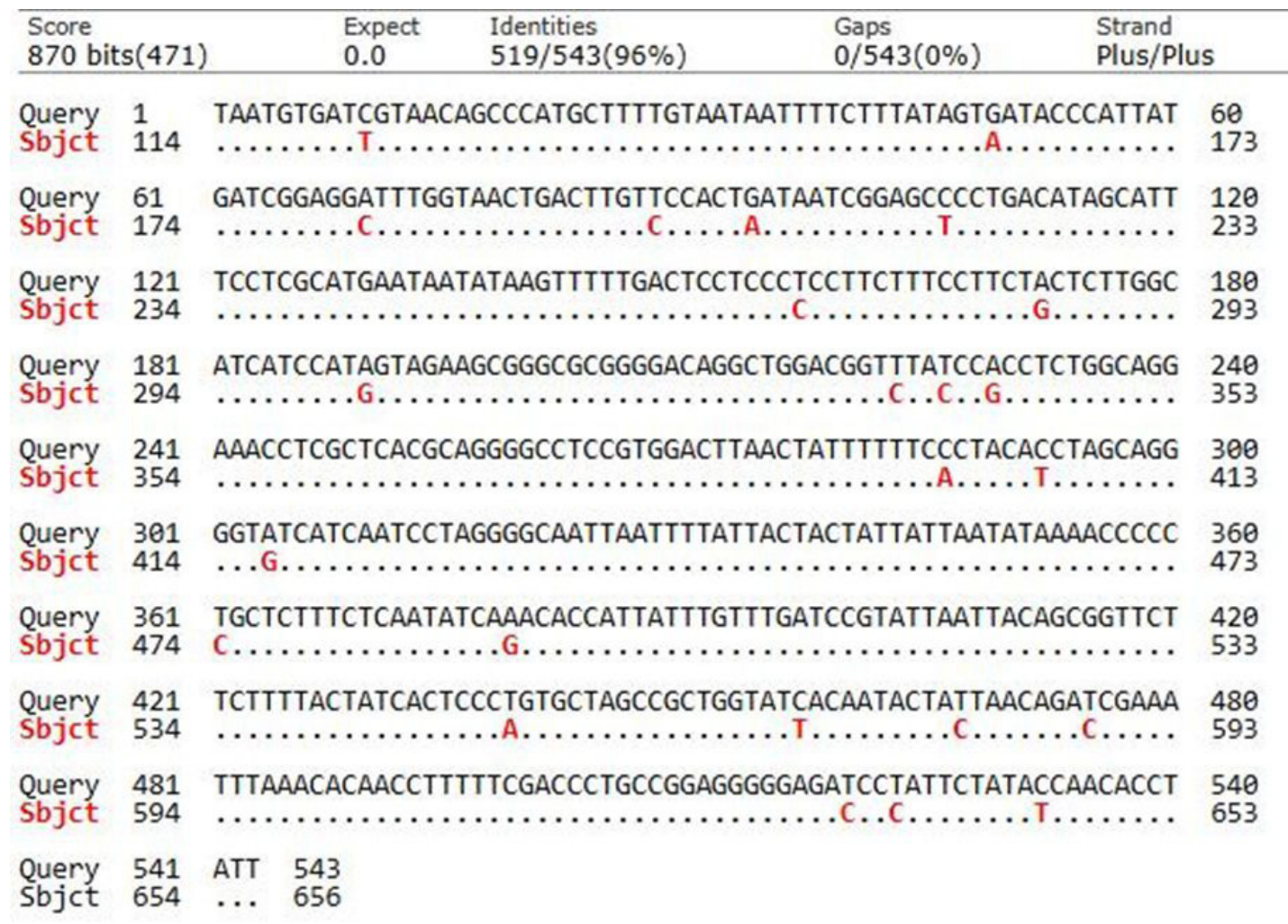

Figure 2. Mutation analysis of representative sequence of specimen collected from (Kahna/District Lahore KA-III) with top second BLAST search result of species Pipistrellus tenuis from Vietnam (Accession No: HM541298). 
Table 2. Within species mean K2P sequence distances based on COI gene and between Pipistrellus coromandra species from this study with conspecifics and congeneric species from other countries.

\begin{tabular}{clcccc}
\hline Sr. No. & \multicolumn{1}{c}{ Species groups } & $\begin{array}{c}\text { Geographical } \\
\text { location }\end{array}$ & $\mathbf{n}$ & $\begin{array}{c}\text { Mean K2P } \\
\text { sequence } \\
\text { distances within } \\
\text { species (\%) } \pm \text { SE }\end{array}$ & $\begin{array}{c}\text { Between group mean K2P } \\
\text { sequence distances (\%) } \pm \text { SE } \\
\text { (P. coromandra from current } \\
\text { study \& other species groups) }\end{array}$ \\
\hline 1. & P. coromandra (Current study) & Punjab, Pakistan & 19 & $0.073 \pm 0.07$ & NC \\
2. & Pipistrellus sp. (Current study) & Punjab, Pakistan & 1 & NC & $24.96 \pm 3.40$ \\
3. & P. tenuis & Laos & 9 & $0.54 \pm 0.195$ & $5.07 \pm 1.04$ \\
4. & P. cf. coromandra & Laos & 3 & $0.422 \pm 0.2344$ & $19.14 \pm 2.80$ \\
5. & P. cf. coromandra & Vietnam & 1 & $\mathrm{NC}$ & $19.14 \pm 2.84$ \\
6. & P. coromandra & Vietnam & 18 & $0.92 \pm 0.242$ & $19.05 \pm 2.76$ \\
7. & P. cf. tenuis & Vietnam & 2 & $1.27 \pm 0.521$ & $5.31 \pm 1.06$ \\
8. & P. cf. coromandra & China & 3 & $2.2 \pm 0.579$ & $17.32 \pm 2.55$ \\
9. & P. tenuis & Vietnam & 18 & $0.35 \pm 0.1569$ & $5.42 \pm 1.08$ \\
10. & P. coromandra & India & 2 & $15.65 \pm 2.33$ & $10.06 \pm 1.39$ \\
11. & P. coromandra & Unknown country & 2 & 0.00 & $20.95 \pm 2.92$ \\
12. & P. cf. coromandra & Pakistan, Tribal areas & 1 & $\mathrm{NC}$ & $19.01 \pm 2.8$ \\
\hline
\end{tabular}

${ }^{*} \mathrm{NC}=$ Non-calculable

Table 3. Diversity indices including total number of Haplotypes (Ht), Haplotype diversity (Hd \pm SD) and Nucleotide diversity ( $\pi \pm$ SD) calculated for sequences analyzed in the current study with sequence data of similar and closely related species from other countries taken from BOLD.

\begin{tabular}{llcccc}
\hline \multicolumn{1}{c}{ Groups Indices } & Geographical location & $\mathbf{n}$ & Ht & Hd \pm SD & $\pi \pm$ SD \\
\hline P. coromandra (Current study) & Punjab, Pakistan & 19 & 2 & $0.351 \pm 0.111$ & $0.00072 \pm 0.00023$ \\
Pipistrellus sp. (Current study) & Punjab, Pakistan & 1 & $\mathrm{NC}$ & $\mathrm{NC}$ & NC \\
P. tenuis & Laos & 9 & 5 & $0.861 \pm 0.087$ & $0.00468 \pm 0.00069$ \\
P. cf. coromandra & Laos & 3 & 3 & $1.00 \pm 0.272$ & $0.00488 \pm 0.00182$ \\
P. cf. coromandra & Vietnam & 1 & $\mathrm{NC}$ & $\mathrm{NC}$ & $\mathrm{NC}$ \\
P. coromandra & Vietnam & 18 & 6 & $0.797 \pm 0.066$ & $0.00889 \pm 0.00284$ \\
P. cf. tenuis & Vietnam & 2 & 2 & $1.000 \pm 0.500$ & $0.01099 \pm 0.00549$ \\
P. cf. coromandra & China & 3 & 3 & $1.000 \pm 0.272$ & $0.02028 \pm 0.00841$ \\
P. tenuis & Vietnam & 18 & 3 & $0.386 \pm 0.128$ & $0.00318 \pm 0.00104$ \\
P. coromandra & India & 2 & 2 & $1.00 \pm 0.500$ & $0.11905 \pm 0.05952$ \\
P. coromandra & Reference sequences & 2 & 1 & $0 \pm 0$ & $0 \pm 0$ \\
P.cf. coromandra & Pakistan, tribal areas & 1 & $\mathrm{NC}$ & $\mathrm{NC}$ & $\mathrm{NC}$ \\
All sequences & -- & 79 & 27 & $0.913 \pm 0.018$ & $0.08165 \pm 0.00497$ \\
\hline
\end{tabular}

${ }^{*} \mathrm{NC}=$ Non-calculable

P. coromandra population from India with lower $\pi$ of $(0.00318$ \pm 0.00104 ) for P. tenuis from Vietnam (see Table 3).

\section{Discussion}

In Pakistan, despite huge diversity of bats, the information on the genetic structure and diversity of this group is highly scarce. The current research work has therefore been planned and successfully yielded the barcode data of species $P$. coromandra belonging to family
Vespertilionidae captured from different locations from Punjab, Pakistan.

The sequences of all specimens generated in the current study had shown close similarity matches with $P$. coromandra from India and P. tenuis from Vietnam on BLASTN. These results are consistent with previous findings by Clare et al. (2007) and (2011) in which 98\% of Neotropical bats species were reliably identified based on barcode gene.

In the current study regarding one specimen (OR-V) barcode sequence had shown entirely different BLASTN 


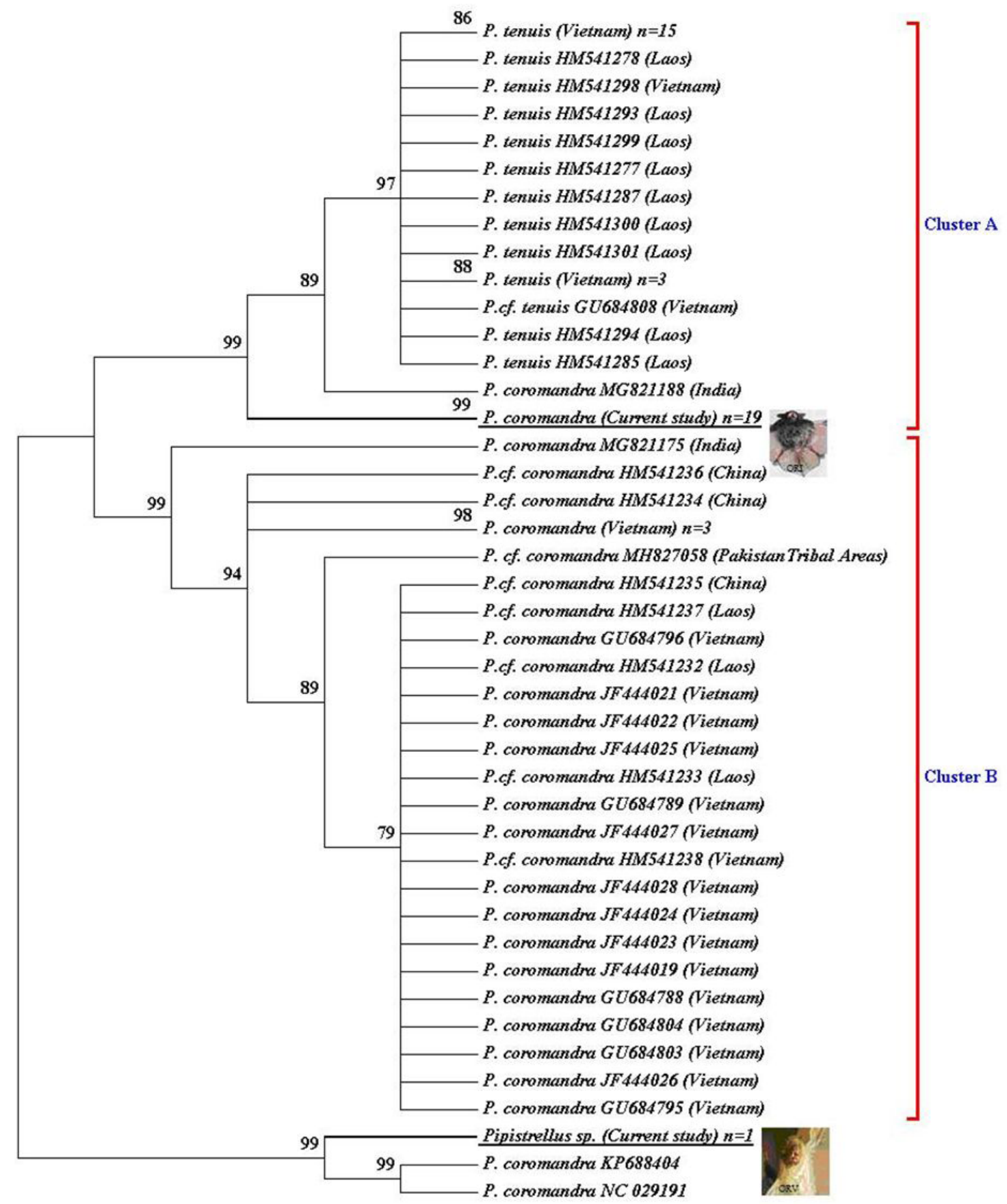

Figure 3. Neighbour-joining tree of genetic similarity based on COI gene. Data consisted of sequences from this study ( $\mathrm{n}=20)$ and sequence data of closely related and similar species from other countries $(\mathrm{n}=59)$. Numbers at nodes are bootstrap support percentages of 70 or greater. The evolutionary distances were computed using the Kimura 2-parameter method (Kimura, 1980) in MEGA7.

results compared with other specimens captured from the same location. The top first BLASTN result had shown 87\% identity match with species Pipistrellus pipistrellus from Russia therefore the species could only be identified to genus level (Pipistrellus sp.) because of no significant similarity matches with the public data. Several ecomorphological studies have suggested the co-existence of morphologically similar species in bats communities (Aldridge and Rautenbach, 1987; Saunders and Barclay, 1992; Jones, 1997; Kingston et al., 2000). It has been a general notion that bats belonging to genus Pipistrellus had shown little morphological variation even with distant member of this group (Hill, 1991; Nowak and Walker, 1994) and depends largely on DNA sequence data for 
their evolutionary relationships which had also revealed significant convergence among the species (Mayer and Helversen, 2001).

Regarding genetic distances the data had shown negligible value between the different populations of $P$. coromandra analyzed in the current study indicating the relatively homogeneous populations. Previously Ward (2009) reported that samples which had no divergence or only the difference of few base pairs are most likely to be the same species. When the comparison of sequences from the current study was made with populations of similar (P. coromandra) and closely related species (P. tenuis) from other geographical regions, it had shown high genetic distances ranging from $(10.06 \pm 1.39)$ to $(20.95 \pm 2.92)$ and $(5.07 \pm 1.04)$ to $(5.42 \pm 1.08)$ indicating the cryptic diversity. K Lim and Arcila Hernandez (2016) compared the DNA barcodes of Jamaican bat with populations of the same species and closely related species from other parts of Neotropics to assess the level of genetic diversity. It was found that the Jamaican samples had an average sequence divergence of $16 \%$ from other Pteronotus parnellii species of continental mainland. Such level of genetic difference had already been reported based on another protein-coding mitochondrial gene, cytochrome b between other species of Pteronotus and congeneric bats (Baker and Bradley, 2006).

In the present study we found high levels of genetic divergence with geographically isolated conspecifics and congeneric species. Bradley and Baker (2001) introduced a criteria for evaluating genetic diversity at mtDNA molecular marker that $<2 \%$ mean sequence divergence could be accounted as intraspecific variation, the values between 2 and 11\% would be considered as cryptic species diversity and needed further taxonomic verification whereas $>11 \%$ reflecting the presence of other congeneric species. Herbert et al. (2003) reported a large data consisting of 13,320 species pairs to determine the sequence divergences in COI gene of congeneric species. It was found that $>2 \%$ sequence divergence was shown by $>98 \%$ of species pairs. Many studies have confirmed that intraspecific divergences are mostly $<1 \%$ and seldom $>2 \%$ (Avise, 2000) but higher divergences could be reflecting the geographical isolation or taxonomic uncertainties where lineages might share a species epithet and their actual status is unclear (Avise and Walker, 1999). Substantial intraspecific variations with mean K2P genetic distances $>2 \%$ were reported in DNA barcodes of five Vespertilionidae species investigated from Italy revealing the presence of cryptic species and require additional taxonomic investigations (Galimberti et al., 2012).

High level of inter and intraspecific genetic divergences in the current study indicating the definite genetic structuring of this species in this region which needs to be further analyzed with samples across the country. Similarly, in another study the bat fauna was used as a model to analyze the value of DNA barcodes for evaluating the taxonomy and distribution of Southeast Asian mammals (Francis et al. 2010). The level of genetic differentiation varied among the species with minimum interspecific distances among species belonging to family Rhinolophidae from $8.6 \%$ (SE 1.0\%) to maximum of $17.1 \%$ (SE 0.8\%) among species from family Vespertilionidae.
Further analysis of NJ tree incorporating the sequences of two species $P$. coromandra \& P. tenuis from other countries placed sequences of $P$. coromandra from the current study with two sequences of same species from India. Whereas the species ( $P$. coromandra) from the current study was found to cluster on same node with $P$. tenuis species from other countries indicating that the two species might exist as sympatric populations. As in bats the sympatry of very similar looking species has been found to be common (Barratt et al., 1997; Von Helversen et al., 2001; Ibáñez et al., 2006). Following the results of the study conducted by (Gager et al., 2016) the results of the phylogenetic reconstructions provided the evidence that the two bats species Molossus coibensis and Molossus molossus occurred in sympatry in Panama and were found from the same building making species-specific social groups. Similar studies have also reported the sympatry of these two species from province of Napo in Ecuador (Clare et al., 2011; McDonough et al., 2011). The only sequence identified as Pipistrellus sp. from the current study had clustered away from the two species $P$. coromandra \& P. tenuis and needs to be further investigated as the animal was roosting with $P$. coromandra specimens captured from sampling location Chak No. 23/2L/District Okara.

A total of 27 haplotypes were found in the total dataset of 79 sequences of COI gene which were analyzed. The measures of genetic diversity (haplotype \& nucleotide diversity) were higher for $P$. coromandra species from India with least diversity indices calculated for $P$. coromandra species from the current study partly due to sampling from only Punjab, Pakistan. Bagi et al. (2018) studied the genetic diversity of Eurasian Collared Dove (Streptopelia decaocto) from Europe, Asia and the Caribbean based on cytochrome oxidase I (COI) gene. The study reported 52 haplotypes and relatively high haplotype $(\mathrm{Hd} \pm \mathrm{SD}=0.843 \pm 0.037)$ and nucleotide diversities $(\pi \pm S D=0.026 \pm 0.013$ ) homogeneously distributed within each geographical region indicating that the population is large and expanding (Avise, 2004).

\section{Conclusion}

The current study successfully proved the power of COI gene as a molecular marker for species identification and in determining the genetic diversity. The comparison of intra and interspecific genetic distances with congeneric and conspecifics species form populations of other countries had revealed high divergence in sequences indicating the cryptic diversity of this species in the country but needs to be further investigated with collections from across the country. There is an urgent need to conduct such studies in Pakistan which will not only help to describe the genetic diversity of bats species in the country but will also help in their conservation and management.

\section{Acknowledgments}

This research did not receive any grant from funding agencies in the public, commercial, or not-for-profit sectors. 


\section{References}

AHMAD, Z., ABBASI, M., SHEIKH, N. and AHMAD, S., 2019. Molecular identification of bats from Punjab-Pakistan. Journal of Biological Regulators and Homeostatic Agents, vol. 33, no. 1, pp. 151-155. PMid:30761812.

ALDRIDGE, H. and RAUTENBACH, I., 1987. Morphology, echolocation and resource partitioning in insectivorous bats. Journal of Animal Ecology, vol. 56, no. 3, pp. 763-778. http://dx.doi. org/10.2307/4947.

AVISE, J., 2004. Molecular markers, natural history, and evolution. 2nd ed. Sunderland, MA: Sinauer Associates.

AVISE, J.C., 2000. Phylogeography: the history and formation of species. Harvard university press. $464 \mathrm{p}$.

AVISE, J.C. and WALKER, D., 1999. Species realities and numbers in sexual vertebrates: perspectives from an asexually transmitted genome. Proceedings of the National Academy of Sciences of the United States of America, vol. 96, no. 3, pp. 992-995. http:// dx.doi.org/10.1073/pnas.96.3.992. PMid:9927681.

BAGI, Z., DIMOPOULOS, E.A., LOUKOVITIS, D., ERAUD, C. and KUSZA, S., 2018. MtDNA genetic diversity and structure of Eurasian Collared Dove (Streptopelia decaocto). PLoS One, vol. 13, no. 3, pp. e0193935. http://dx.doi.org/10.1371/journal.pone.0193935. PMid:29518164.

BAKER, R.J. and BRADLEY, R.D., 2006. Speciation in mammals and the genetic species concept. Journal of Mammalogy, vol. 87, no. 4, pp. 643-662. http://dx.doi.org/10.1644/06-MAMM-F-038R2.1. PMid:19890476.

BARRATT, E., DEAVILLE, R., BURLAND, T., BRUFORD, M.W., JONES, G., RACEY, P. and WAYNE, R., 1997. DNA answers the call of pipistrelle bat species. Nature, vol. 387, no. 6629, pp. 138-139. http://dx.doi.org/10.1038/387138b0. PMid:9144281.

BATES, P.J.J. and HARRISON, D.L., 1997. Bats of the Indian subcontinent. Sevenoaks, UK: Harrison Zoological Museum, 258 p.

BORISENKO, A.V., LIM, B.K., IVANOVA, N.V., HANNER, R.H. and HEBERT, P.D., 2008. DNA barcoding in surveys of small mammal communities: a field study in Suriname. Molecular Ecology Resources, vol. 8, no. 3, pp. 471-479. http://dx.doi. org/10.1111/j.1471-8286.2007.01998.x. PMid:21585824.

BRADLEY, R.D. and BAKER, R.J., 2001. A test of the genetic species concept: cytochrome-b sequences and mammals. Journal of Mammalogy, vol. 82, no. 4, pp. 960-973. http://dx.doi. org/10.1644/1545-1542(2001)082<0960:ATOTGS>2.0.CO;2.

CLARE, E.L., 2011. Cryptic species? Patterns of maternal and paternal gene flow in eight Neotropical bats. PLoS One, vol. 6, no. 7, pp. e21460. http://dx.doi.org/10.1371/journal.pone.0021460.

CLARE, E.L., LIM, B.K., ENGSTROM, M.D., EGER, J.L. and HEBERT, P.D., 2007. DNA barcoding of Neotropical bats: species identification and discovery within Guyana. Molecular Ecology Notes, vol. 7, no. 2, pp. 184-190. http://dx.doi.org/10.1111/j.14718286.2006.01657.x.

CLARE, E.L., LIM, B.K., FENTON, M.B. and HEBERT, P.D. 2011. Neotropical bats: estimating species diversity with DNA barcodes. PLoS One, vol. 6, no. 7, pp. e22648. http://dx.doi. org/10.1371/journal.pone.0022648.

FAN, H. and GULLEY, M.L. 2001. DNA extraction from fresh or frozen tissues. In: A.A. KILLEEN. Molecular Pathology Protocols. Springer, pp. 5-10.

FRANCIS, C.M., BORISENKO, A.V., IVANOVA, N.V., EGER, J.L., LIM, B.K., GUILLÉN-SERVENT, A., KRUSKOP, S.V., MACKIE, I. and HEBERT, P.D. 2010. The role of DNA barcodes in understanding and conservation of mammal diversity in Southeast Asia. PLoS One, vol. 5, no. 9, pp. e12575. http://dx.doi.org/10.1371/journal.pone.0012575.
GAGER, Y., TARLAND, E., LIECKFELDT, D., MÉNAGE, M., BOTEROCASTRO, F., ROSSITER, S.J., KRAUS, R.H., LUDWIG, A. and DECHMANN, D.K. 2016. The value of molecular vs. morphometric and acoustic information for species identification using sympatric molossid bats. PLoS One, vol. 11, no. 3, pp. e0150780. http://dx.doi.org/10.1371/journal.pone.0150780.

GALIMBERTI, A., SPADA, M., RUSSO, D., MUCEDDA, M., AGNELLI, P., CROTTINI, A., FERRI, E., MARTINOLI, A. and CASIRAGHI, M. 2012. Integrated operational taxonomic units (IOTUs) in echolocating bats: a bridge between molecular and traditional taxonomy. PLoS One, vol. 7, no. 6, pp. e40122. http://dx.doi.org/10.1371/ journal.pone.0040122.

HAJIBABAEI, M., JANZEN, D.H., BURNS, J.M., HALLWACHS, W. and HEBERT, P.D., 2006. DNA barcodes distinguish species of tropical Lepidoptera. Proceedings of the National Academy of Sciences of the United States of America, vol. 103, no. 4, pp. 968-971. http://dx.doi.org/10.1073/pnas.0510466103. PMid:16418261.

HERBERT, P., RATNASINGHAM, S. and DEWAARD, R. 2003. Barcoding animal life: cytochrome $c$ oxidase subunit 1 divergences among closely related species. Proceedings of the Royal Society of London. Series B: Biological Sciences, vol. 270, Suppl. 1, pp. S96-S99. https://doi.org/10.1098/rsbl.2003.0025.

HILL, J.E., 1991. A world list of mammalian species. Natural History Museum, Cambridge University Press.

IBÁÑEZ, C., GARCÍA-MUDARRA, J.L., RUEDI, M., STADELMANN, B. and JUSTE, J., 2006. The Iberian contribution to cryptic diversity in European bats. Acta Chiropterologica, vol. 8, no. 2, pp. 277297. http://dx.doi.org/10.3161/1733-5329(2006)8[277:TICT CD]2.0.CO;2.

JAVID, A., RASHEED, B., ZEB, J. and KHAN, M.I., 2019. Morphological Differentiation in Some Pipistrellus sp. (Chiroptera) Captured from Bajaur Agency, Pakistan. Pakistan Journal of Zoology, vol. 51, no. 2, pp. 689. http://dx.doi.org/10.17582/journal. pjz/2019.51.2.689.695.

JONES, G. 1997. Acoustic signals and speciation: the roles of natural and sexual selection in the evolution of cryptic species. Advances in the Study of Behaviour, vol. 26, pp. 317-354.

K LIM, B. and ARCILA HERNANDEZ, L.M., 2016. DNA barcoding of Jamaican bats: implications to Neotropical biodiversity. Mitochondrial DNA. Part A, DNA Mapping, Sequencing, and Analysis, vol. 27, no. 4, pp. 3013-3019. http://dx.doi.org/10.31 09/19401736.2015.1063047. PMid:27158792.

KERR, K.C., LIJTMAER, D.A., BARREIRA, A.S., HEBERT, P.D. and TUBARO, P.L. 2009. Probing evolutionary patterns in Neotropical birds through DNA barcodes. PLoS One, vol. 4, no. 2, pp. e4379. http://dx.doi.org/10.1371/journal.pone.0004379.

KERR, K.C., STOECKLE, M.Y., DOVE, C.J., WEIGT, L.A., FRANCIS, C.M. and HEBERT, P.D., 2007. Comprehensive DNA barcode coverage of North American birds. Molecular Ecology Notes, vol. 7, no. 2, pp. 535-543. http://dx.doi.org/10.1111/j.1471-8286.2007.01670.x. PMid: 18784793.

KIMURA, M., 1980. A simple method for estimating evolutionary rates of base substitutions through comparative studies of nucleotide sequences. Journal of Molecular Evolution, vol. 16, no. 2, pp. 111-120. http://dx.doi.org/10.1007/BF01731581. PMid:7463489.

KINGSTON, T., JONES, G., ZUBAID, A. and KUNZ, T., 2000. Resource partitioning in rhinolophoid bats revisited. Oecologia, vol. 124, no. 3, pp. 332-342. http://dx.doi.org/10.1007/PL00008866. PMid:28308770.

KOOPMAN, K.F. 1993. Order Chiroptera. In: D.E. WILSON, ed. Mammal species of the world: A taxonomic and geographic reference. Washington, D.C.: Smithsonian Institution Press, pp. 137-241. 
KUMAR, S., STECHER, G. and TAMURA, K., 2016. MEGA7: molecular evolutionary genetics analysis version 7.0 for bigger datasets. Molecular Biology and Evolution, vol. 33, no. 7, pp. 1870-1874. http://dx.doi.org/10.1093/molbev/msw054. PMid:27004904.

LIBRADO, P. and ROZAS, J., 2009. DnaSP v5: software for comprehensive analysis of DNA polymorphism data. Bioinformatics (Oxford, England), vol.25, no. 11, pp. 1451-1452. http://dx.doi.org/10.1093/ bioinformatics/btp187. PMid:19346325.

MAHMOOD-UL-HASSAN, M., JONES, G. and DIETZ, C. 2009. Bats of Pakistan: The least known mammals. Saarbucken, Germany: Verlag Dr. Muller, $168 \mathrm{p}$.

MAYER, F. and HELVERSEN, O.V., 2001. Cryptic diversity in European bats. Proceedings of the Royal Society of London. Series B, Biological Sciences, vol. 268, no. 1478, pp. 1825-1832. http://dx.doi. org/10.1098/rspb.2001.1744. PMid:11522202.

MCDONOUGH, M.M., FERGUSON, A.W., AMMERMAN, L.K., GRANJAVIZCAINO, C., BURNEO, S.F. and BAKER, R.J. 2011. Molecular verification of bat species collected in Ecuador: results of a country-wide survey. Occasional papers, Museum of Texas Tech University, vol. 301, pp. 1-28.

NOWAK, R.M. and WALKER, E.P., 1994. Walker's bats of the world. Baltimore: JHU Press.

REEDER, D.M., HELGEN, K.M. and WILSON, D.E. 2007. Global trends and biases in new mammal species discoveries. Occasional Papers, Museum of Texas Tech University, no. 269, pp. 1-35.
ROBERTS, T., 1997. The mammals of Pakistan. Karachi, Pakistan: Oxford University Press, 525 p.

SAITOU, N. and NEI, M., 1987. The neighbor-joining method: a new method for reconstructing phylogenetic trees. Molecular Biology and Evolution, vol. 4, no. 4, pp. 406-425. http://dx.doi. org/10.1093/oxfordjournals.molbev.a040454. PMid:3447015.

SAUNDERS, M.B. and BARCLAY, R.M., 1992. Ecomorphology of insectivorous bats: a test of predictions using two morphologically similar species. Ecology, vol. 73, no. 4, pp. 1335-1345. http://dx.doi.org/10.2307/1940680.

VON HELVERSEN, O., HELLER, K.-G., MAYER, F., NEMETH, A., VOLLETH, M. and GOMBKÖTÖ, P., 2001. Cryptic mammalian species: a new species of whiskered bat (Myotis alcathoe n. sp.) in Europe. Naturwissenschaften, vol. 88, no. 5, pp. 217-223. http://dx.doi.org/10.1007/s001140100225. PMid:11482435.

WARD, R.D., 2009. DNA barcode divergence among species and genera of birds and fishes. Molecular Ecology Resources, vol. 9, no. 4, pp. 1077-1085. http://dx.doi.org/10.1111/j.17550998.2009.02541.x. PMid:21564845.

WARD, R.D., ZEMLAK, T.S., INNES, B.H., LAST, P.R. and HEBERT, P.D., 2005. DNA barcoding Australia's fish species. Philosophical Transactions of the Royal Society of London. Series B, Biological Sciences, vol. 360, no. 1462, pp. 1847-1857. http://dx.doi. org/10.1098/rstb.2005.1716. PMid:16214743. 